This is an author produced version of a paper published in Post-Communist Economies.

This paper has been peer-reviewed and is proof-corrected, but does not include the journal pagination.

Citation for the published paper:

Svetlana Golovina, Sebastian Hess, Jerker Nilsson \& Axel Wolz. (2014)

Social capital in Russian agricultural production co-operatives. Post-

Communist Economies. Volume: 26, Number: 4, pp 522-536.

http://dx.doi.org/10.1080/14631377.2014.964465.

Access to the published version may require journal subscription.

Published with permission from: Taylor \& Francis.

Standard set statement from the publisher:

This is an Accepted Manuscript of an article published by Taylor \& Francis in Post-Communist Economies on 30 oct 2014, available online:

http://wwww.tandfonline.com/10.1080/14631377.2014.964465.

Epsilon Open Archive http://epsilon.slu.se 


\title{
Social Capital in Russian Agricultural Production Co-operatives
}

\author{
Svetlana Golovina ${ }^{\mathrm{a}}$, Sebastian Hess ${ }^{\mathrm{b}}$, Jerker Nilsson ${ }^{\mathrm{c}}$ and Axel Wolz $^{\mathrm{d}}$ \\ ${ }^{a}$ Kurgan State Agricultural Academy, Russia; ${ }^{b}$ Department of Economics, Swedish \\ University of Agricultural Sciences, Sweden; ${ }^{c}$ Department of Economics, Swedish \\ University of Agricultural Sciences, Sweden;; ${ }^{d}$ External Environment for Agriculture and \\ Policy Analysis, Leibniz Institute of Agricultural Development in Transition Economies, \\ Germany
}

When the Soviet kolkhozes and sovkhozes were converted, a large number of agricultural production co-operatives was created. Most of these co-operatives still exist in Russia and some of them have a strong market position, accounting for almost one-third of the aggregate volume produced by large farms. This study explored whether social capital might be the explanation for this relative success, i.e. that members support their cooperative because they trust their fellow members as well the leadership. Interviews with co-operative members resulted in 1401 usable answers. The results from an Ordered Logit Model indicated that social capital plays a partial role. Members who consider cooperatives to be an efficient business form value social ties to other members, even though the leadership does not enjoy much social capital.

\section{Introduction}

\section{Production co-operatives in Russian agriculture}

On the basis of a survey of members of Russian agricultural production co-operatives, this study explored whether the social capital among members explains their view of this organizational form and why it is still relevant in Russian agriculture.

In the late 1980s, the first steps were taken towards the transformation of the state and collective farms (sovkhozes and kolkhozes) which characterized Soviet agriculture (Ellman 1991). In principle, these farms could have been re-organized as individual (family) farms, investor-owned firms (i.e. limited liability or joint-stock companies) or agricultural production co-operatives, formally based on voluntary membership. It has been observed that no voluntarily established agricultural production co-operatives are to be found in any longterm settled farming village world-wide (Schiller, 1969). Similarly, investor-owned firms play a marginal role in the Western world's agricultural production, with the exception of plantations (Schmitt, 1993).

There is a widely held opinion among agricultural economists that family farms are the most competitive model of farm organization. It is argued that within agricultural production, the technological economies of scale are typically exhausted before the farm size exceeds the labour capacity of a family, and further growth of the labour force is inhibited by rising supervision costs (Binswanger et al., 1995; Eastwood et al., 2010). The governance of a family brings advantages due to the smallness of the group and its hierarchical structure, so that shirking and free-riding among family members is restricted (Pollak, 1985). Hence

\footnotetext{
${ }^{1}$ Corresponding author. Email: Jerker.Nilsson@slu.se. Department of Economics, Swedish University of Agricultural Sciences, P.O. Box 7013, SE-750 07 Uppsla, Sweden.
} 
production co-operatives can be expected to have high agency costs and not necessarily low production costs.

After the change of the political regime in the former Soviet Union, most political advisors strongly endorsed the family farm model (Lerman, 1998, 2010). The World Bank (1992, p. 77) expected that "about 40 percent of agricultural land will be farmed privately by the end of 1995". However, during the following years family farming did not develop as anticipated. Large-scale farms registered as investor-owned firms or as agricultural production cooperatives continued to play a powerful role (Uzun, 2008; Ioffe et al., 2012).

Russian agricultural production co-operatives have not only survived for more than two decades, but are also to some extent thriving, as many of them have a strong market position and have high market shares in several agricultural branches and regions of the Russian Federation. In 2009, they constituted about 32 per cent of all large agricultural enterprises and their market share was 33 per cent (Golovina et al., 2013). The co-operatives are involved in a variety of agricultural industries such as breeding and fattening of cattle (39.6 per cent of overall production), potatoes and vegetables (16.6 per cent), and honey and fish production (14.6 per cent) (Petraneva et al., 2005).

\section{Research approach}

The preceding section indicates that there are interesting issues to be investigated concerning the Russian agricultural production co-operatives, including factors that contribute to their survival and relative success. One such factor is whether member support of the co-operative society and the co-operative business firm fosters strength.

An increasing amount of research about agricultural co-operatives in market economies indicates that social forces within the membership body constitute a crucial factor behind the success or failure of these firms (Nilsson and Svendsen, 2011; Nilsson et al., 2012). To be successful, the members must have trust in the co-operative and each other. With limited trust they will not want to support the co-operative, their patronage will decline and they will have a low willingness to fund the co-operatives and to govern it. Hence a possible explanation for the relative strength of Russian production co-operatives is that there is social capital within their membership groups.

The conditions in Russian agriculture are different to those prevailing in Western economies. First, in Western countries co-operatives are basically grass-roots organizations. They are established and develop on the basis of popular movements. They exist because individuals experience economic problems that they could not solve individually, but thanks to joint action they can balance skewed market relations (Staatz, 1984, 1987, 1989). The Russian production co-operatives, on the other hand, are generally former state or collective farms, transformed into co-operative societies. Even though these co-operatives by law must be formed after voluntary decision-making by the farm workers, these workers had a limited degree of freedom when choosing the co-operative form (Golovina et al., 2013). In the establishment phase, the workers were influenced by political forces and the public administration and also subjected to pressure from the kolkhoz and sovkhoz leaders.

Second, the co-operatives in Western agriculture concern inter-organizational relations, as the members are independent farmers. The relationships between members and co-operatives in 
the Russian production co-operatives are intra-organizational. The worker-members are part and parcel of the co-operative organization, not independent units.

Nevertheless, the relative strength of the Russian production co-operatives might indicate that social capital exists in the memberships. The members may have sympathies for each other and trust in the leadership, and may be satisfied with their livelihood. The leadership may have member interests as the guiding principle in their decisions.

A number of previous studies have examined various aspects of Russian production cooperatives. Some of these have focused on the leadership, which is claimed to be more or less autocratic (Amelina, 2000; Lerman et al., 2004; Valentinov and Nedoborovsky, 2007; AllinaPisano, 2008; Petrick and Carter, 2009). The leaders of the co-operatives are strong individuals and the establishment of the co-operatives did not always follow a democratic path. An interpretation of these studies is that the social relationships within the membership groups are of a specific kind. However, no previous study of Russian production cooperatives has adopted a social capital theoretical approach.

All the above-mentioned studies are based on qualitative data collected through observations and personal communications with stakeholders, although not members of the co-operatives. Allina-Pisano (2008, p. xxii) observe that directors "would not allow survey questions to be asked of their workers." These studies are therefore based on rather unsystematically collected data and none has hard quantitative facts from the members to underpin the arguments presented. Hence the conclusions from these studies may be uncertain.

Furthermore, these studies do not address why the co-operatives have survived for more than two decades and are to some extent successful. That would be difficult to achieve if there were not at least some social capital within the membership groups.

The aim of this study is to explore the extent to which the existence of the Russian agricultural co-operatives is based on social capital that the members have in the co-operative organization. The empirical data were obtained through personal interviews with 1401 members of production co-operatives within the Kurgan Region, located east of the Ural Mountains.

The following section presents the social capital theoretical framework, especially as it appears in the context of co-operatives. On the basis of that theoretical presentation, variables and questionnaire items are identified. Next, the empirical approach is presented. Subsequent sections comprise an account of the results, analyses of the findings, a discussion and conclusions.

\section{Theoretical framework}

\section{Social capital theory}

For an individual, a group of individuals or an organization to be able to make decisions concerning future actions, there is need for resources. However, these resources do not consist solely of financial capital. There must also be other types of capital, such as social, physical and human capital and, with respect to agricultural production, natural capital (Ellis, 2000). Human capital implies that the decision-maker has knowledge and skills in relation to appropriate actions such as profitable investment opportunities. 
Social capital is a relatively vague concept in social science (Durlauf and Fafchamps, 2005), but there is common agreement that it matters, as the actions of one human are related to the actions of others. There are interdependencies in social relations. Hence, social capital is an attribute of relationships, whether between two individuals, between an individual and an organizational unit, within an organization, within a network of individuals or organizations, etc. The social capital in relationships may be unequally distributed however, i.e. one of the actors may have trust in a partner, but it may not be reciprocated.

Because social capital can be identified at different levels of the social hierarchy individuals, groups, organizations and society at large - several definitions have been proposed. The present study focuses on social capital at the organizational level. According to Bourdieu (1986, p. 243), social capital is "made up of social obligations ('connections'), which are convertible, in certain conditions, into economic capital and may be institutionalized in the form of a title of nobility". Woolcock (1998, p. 153) defines social capital as "the information, trust, and norms of reciprocity inherent in one's social networks". These definitions are applicable in the present study.

Social capital is as important to human behaviour, business decisions and government action as financial capital. With low trust, much decision-making is difficult. Investors would scarcely buy assets if they did not trust their suppliers to actually deliver the goods, if they believed that their employees would cheat, if they could not rely on the country's judicial system, etc. Trust reduces the transaction and agency costs in interpersonal and organizational settings. It decreases the costs to individuals and organizations of insuring themselves against deceitful behaviour by their partners, both in social life and in business relations (Nilsson et al., 2012). Trust can be higher in some specific small and large social groups than in others, for example in families, neighbourhoods, clubs, workplaces and religious communities.

Previous research shows that the social capital framework is relevant in a co-operative context. If a co-operative society is to enjoy member satisfaction and member loyalty, there must be some form of social relations within the membership (Hakelius, 1996; Borgen, 2001). There must be trust in the sense that the members should have at least some confidence in one another and in the leadership (Morrow et al., 2004; Jones and Kalmi, 2009; Nilsson et al., 2009). A successful co-operative presupposes that members are concerned about how the co-operative is governed (Österberg and Nilsson, 2009). They consider the cooperative to be important for them.

The existence of social capital within an organization may have the effect of inhibiting the individuals' incentive for change. When people regard themselves as group members, they might have less entrepreneurial spirit. The resulting lower economic development is not necessarily a problem, as it may be considered to create a balance between social satisfaction and economic benefits (Svendsen and Svendsen, 2003).

\section{Social capital indicators}

There are various ways of assessing social capital. One approach distinguishes between structural and cognitive forms. Structural social capital facilitates information sharing and collective action through established roles, rules and procedures. It is relatively objective and observable. Cognitive social capital refers to shared norms, values, trust, attitudes and beliefs 
that contribute to co-operative behaviour. It is more subjective and intangible (Uphoff, 1999). The present study focuses on social capital of the cognitive form.

The variables used in previous empirical studies about members' view of their co-operatives comprise a large variety of socio-psychological constructs such as attitudes, knowledge, preferences, solidarity and loyalty, which are related to cognitive social capital. In particular, several studies have focused specifically on members' trust in their co-operative and in its leadership (Borgen, 2001; Hansen, et al., 2002; James and Sykuta, 2005; Österberg and Nilsson, 2009).

In line with Feng et al. (2014), the following four social capital indicators were used in the present study: Involvement, trust, satisfaction and loyalty. Each of these variables was operationalized into one or more items in the questionnaire used in the collection of data.

\section{Variables and questionnaire items}

The dependent variable was the members' view of the production co-operative form in Russia. This attitudinal variable was covered by one question:

"I think that joint farming in a production co-operative is an efficient way of carrying out agricultural production in Russia." The question was answered according to a Likert scale ranging between 1 (Agree) and 6 (Disagree).

The independent variables ${ }^{2}$ consisted of the four social capital constructs, namely involvement, trust, satisfaction and loyalty. Each of these was covered by one or more questions in the questionnaire. The social capital dimensions, questions and variables were as follows:

Involvement. If the members are involved, they are likely to take overt action concerning the production co-operative's operations and wellbeing. For example, they would inform themselves about the financial status, take part in discussions, and be prepared to govern the firm.

- "To what extent do you read the balance sheet and the profit-and-loss account of the annual report?" Likert scale ranging from Very carefully (1) to Not at all (6); variable "D readbalancesheet"

- "Do you always take part in the general assembly meetings?" Likert scale ranging from Every time (1) to Never (6); variable "D_participgenass"

- "Would you be willing to become a member of the leadership?" The response alternatives were: $Y e s=1$ or No $=2$; variable "D_willingleader"

Trust. Trust can be identified both in the individual member's relationship to other members and in his/her view of the leadership.

- "To what extent is it important for you to have friends and relatives close to you within the co-operative (as colleagues)?" Likert scale ranging from Very important (1) to Not important at all (6); variable "closefriendsincoop"

\footnotetext{
${ }^{2}$ The prefix ' $\mathrm{D}_{-}$' in front of a variable name indicates that this variable entered the analysis as a dummy.
} 
- "To what extent does the leadership care about the opinions of the members?" Likert scale ranging from Very much (1) to Not at all (6); variable "D_leadercareopinion"

Satisfaction. The members' degree of satisfaction with the co-operative is a relative concept. Hence, it may be compared against the conditions before establishment of the co-operative, as well as the attractiveness of private farming.

- "Compared with the situation of collective/state farms, i.e. during the time of the Soviet Union, do you think that you - as an ordinary member - have more influence in decision-making now?" The response alternatives were: Yes $=1 ;$ No $=2$; Too young $=3$; variable "D_ordinarymeminfluence"

- "Since you became a member of the production co-operative, have you considered the option of becoming a family farmer?" The response options were: Yes $=1$ or No $=2$; variable "D_consideredfamfarmlater"

Loyalty. Loyalty may be both an expression of an individual's propensity to act and the individual's actual behaviour. The latter interpretation cannot be used here, as the members have limited possibilities to express dissatisfaction through disloyalty. Hence loyalty must be measured in terms of opinions.

- "To what extent does it happen that the members have positive opinions about the way the co-operative is run?" Likert scale ranging between Very often (1) to Never (6); variable "D_posopinioncoop"

\section{Empirical basis}

To obtain data for analysis of the above-mentioned variables, an empirical study was carried out. A structured questionnaire was designed, comprising questions based on the dependent and independent variables and the socio-economic variables. Data were collected in a survey conducted by one of the authors and 54 of her students through personal interviews, supplemented by phone and through mail. The interviewing students were specifically trained for this task so that best possible conformity could be attained. The data collection took place in August, September and October 2011 within the Kurgan region.

The Kurgan Region, which covers 71,500 square kilometres, is part of the Federal Region of Ural, and lies east of the Ural mountain ridge. The region is located in the south-western part of the Siberian lowland, and borders Kazakhstan to the south. Of its total population of 908,800 (2010), almost half (43\%) live in rural areas. The regional economy is dominated by agriculture, with an agricultural area comprising about four million hectares, of which 2.2 million are arable land. Agricultural production makes up $18 \%$ of the gross regional product. Agro-food industries are the dominant source of employment and income in the region's economy (Kurganrosstat, 2011).

The sampling of the respondents took place in two steps. First, 45 of the 73 agricultural production co-operatives in the Kurgan Region were selected. This was a convenience sample, as the students held interviews in their home villages and neighbouring villages. There is no reason to suspect that this procedure resulted in a non-representative sample. All 24 districts of the Kurgan region were covered. Second, the students selected rank-and-file members in each co-operative. The respondents included both those who became members of 
agricultural production co-operatives when the kolkhozes and sovkhozes were restructured, i.e. they participated in the transition process, and those who joined after the transition.

The students approached 1792 co-operative members. Some of the intended respondents abstained, while others gave incomplete answers. After a check of consistency, some open issues were covered by mail or phone. Hence a response rate of $78.2 \%$ was achieved, i.e. the number of usable answers which formed the data set of the analyses was 1401 . The socioeconomic structure of the sample is shown in Table 1.

\section{>> Insert Table 1 here or somewhat below $<<$}

The average age of respondents was relatively low, about 43 years. Younger people did not seem to turn to other professions or move to other regions, but stayed with the production cooperative. The proportion of people younger than 35 years was more than 30 per cent. Females formed the majority of the sample. This proportion is quite large, as according to the Russian Census of 2006, the proportion of female agricultural staff is about 40 percent (Wegren, 2014). Almost half the respondents were household heads, of households comprising 3-4 people. This is relatively large, as the average Russian rural households has 2.8 members (Wegren, 2014, p. 103).

The educational level among respondents was relatively high. More than four-fifths of the respondents had a diploma in a specialist course, from a college or even from a university. With this relatively good educational level, it has to be assumed that a high proportion of younger people might have left the co-operative. On the other hand, formal agricultural education was rather low. More than one-third of the respondents had not taken any course, but just received "on-the-job training" and about one-quarter had attended agricultural college or university. Although the proportion of young members was relatively high, more than half of all respondents had already joined the preceding farm during the time of the Soviet Union. They were actively involved in the transformation of their farm during the early 1990s.

\section{Analyses}

\section{Descriptive analysis}

The basic attributes of the eight social capital indicators identified are shown in Table 2. A first impression is that the members are locked-in with their co-operative. They reported being not very fond of it, but valued the collaboration with close relatives and friends. Similarly, they believed that becoming a private farmer, which is the most likely alternative to their present situation, is not attractive.

\section{$>$ Insert Table 2 here or somewhat below $<<$}

Involvement. The members' involvement in the co-operative was quite low. Relatively few bothered to read the co-operative's annual reports and even fewer attended the annual assemblies. Only few respondents reported being prepared to stand for board elections and take over leadership responsibilities. 
Trust. With respect to the dimension "trust", a large proportion of the respondents stated that it is important to them to work together with relatives and friends in the co-operative. There was a slightly negative response regarding whether the co-operative leadership cares about the opinions of the members.

Satisfaction. Most members considered themselves dissatisfied with their influence on decision-making in the co-operative. Those who used to work on the preceding farm during the Soviet times reported that ordinary members do not have more influence in decision making these days. For them, not much seems to have changed. On the other hand, just a small proportion of the respondents reported having considered the option of becoming private farmer after the transformation into an agricultural production co-operative, i.e. during recent years.

Loyalty. With respect to "loyalty", the majority of the respondents stated that most members do not have positive opinions about their co-operative. They claimed that negative opinions dominate.

\section{Econometric analysis}

The dependent variable of the econometric analysis was comprised of responses to the survey question "I think that joint farming in a production co-operative is an efficient way of carrying out agricultural production in Russia." Thus, the dependent variable was a measure of stated relative scepticism with respect to the production efficiency of the co-operative model among survey respondents.

This six-point Likert scale can be viewed as an approximation of the 'true' underlying, yet unobservable, continuous distribution of the relative scepticism. Therefore, the method of analysis had to account for the fact that the 'true' value of the dependent variable remained unobserved, but was approximated through the observed categorical responses on the Likert scale.

Hence, an Ordered Logit model was employed, using the previously discussed measures of social capital as explanatory variables. Using an Ordered Logit model (along with ordered probit models) is a well-established estimation approach if the dependent variable $y$ is discrete while the order of discrete categories has a meaningful interpretation such as "increasing order of answers" or, in the present case, Likert categories 1 to 6 implying successively higher levels of scepticism regarding the degree to which the co-operative may be an efficient way to organize agricultural production in Russia.

The regression model thus took the general form $y^{*}=x^{\prime} \beta+\varepsilon$, with $x$ representing explanatory variables, $\beta$ the corresponding estimated coefficients and $\varepsilon$ a stochastic error term. However, the variable $y_{i}{ }^{*}$ represents only the respondents' 'true' level of attitude regarding the cooperative model, which unfortunately remained unobservable for the $i=1, \ldots, n$ respondents. Instead, the observed counterpart was a corresponding discrete variable, $y_{i}$, which is the abovementioned measure of relative scepticism based on the Likert-scale answers.

In general, the Ordered Logit model applies to surveys in which the dependent variable represents an ordinal ranking (as in the present case increasing scepticism with respect to the co-operative model): $y=$ Likert category $1<y=$ Likert category 2 , etc.), while the more frequently used multinomial logit model does not restrict the discrete outcomes to be ordered 
(e.g. $y=$ "wheat" versus $y=$ "maize", etc. would be sufficient for a multi-nominal approach but not for an ordered approach).

Ordered Logit models can either be estimated based on Maximum Likelihood, as done here, or through Bayesian methods. The probabilities which enter the log likelihood function can be stated as follows (Greene and Hensher, 2008):

$$
P\left(y_{i}=j\right)=P\left(y_{i}^{*} \text { falls within the } j^{\text {th }} \text { category of } y_{i}\right)
$$

With this approach, the empirical effect of each explanatory variable on the probability of a respondent's stated scepticism falling into one of the observed $j=1, \ldots, 6$ (Likert) categories of the dependent variable is estimated. A disadvantage of the Ordered Logit approach is that marginal effects on $y$ of a 1-unit change in $x$ are not directly given by the estimated coefficients. Therefore, neither the sign nor the magnitude of the estimated $\beta$ receives a direct interpretation. Instead, marginal (also known as "partial") effects have to be calculated separately (Greene, 2003) according to the first-order partial derivatives:

$$
\frac{\partial P\left(y_{i}=j \mid x\right)}{\partial x}
$$

Table 3 presents the estimates of these average marginal effects from the Ordered Logit model after elimination of multicollinear and non-significant variables. In order to detect multicollinearity, Variance Inflation Factors (VIF) were computed and VIF values up to the critical level of 10 were tolerated. The marginal effects in Table 3 were calculated using the Delta method implemented in Stata's postestimation commands. The coefficients (dy/dx) in Table 3 reflect the estimated change in the dependent variable after a 1-unit change in the corresponding explanatory variable. The Ordered Logit model underlying Table 3 predicts about one-third of cases correctly.

>> Insert Table 3 here or somewhat below $<<$

\section{Results}

\section{Overview}

The model chosen follows the approach of a social capital perspective. Table 3 only lists those variables which were retained in the regression model after less significant similar variables and those with high degrees of collinearity to the existing variables were dropped. Several significant explanatory variables suggested an influence on the dependent variable. However, the overall explanatory power of only about one-third of cases being predicted correctly is rather limited. This suggests that the social capital approach can only provide a partial explanation. If the social capital approach had been the only one, the explanatory power would most likely have been higher. However, the possibility cannot be ruled out that some of the variables in the dataset also contained a certain degree of measurement error that may be part of the normally distributed random error term.

Most socio-economic variables such as age, household size and length of employment in the co-operative did not turn out to be important for the members' evaluation of the co-operative 
business form. Gender had a slight but non-significant influence on the members' evaluation. The only socio-economic variable with a significant influence was agricultural education.

agriceducation: The agricultural production co-operative model is viewed as an efficient model by those with a better agricultural education.

The fact that members with a better agricultural education were more satisfied with the cooperative model may be explained by their better skills when working within co-operatives. Therefore, they may have a stronger position in the social networks and better possibilities to understand the links between their own (and other members') work and the outcomes from the agricultural production.

The four social capital dimensions which may have had an influence on the members' evaluation of the co-operative business form are discussed in more detail below. Three of these provide explanations for the members' positive or negative view of the co-operatives. The indicator that did not show any impact was "Satisfaction". Members" evaluation of the business form was not influenced by this dimension, as they considered themselves to have almost no influence in the decision-making.

\section{Involvement}

D_readbalancesheet_2: Agricultural production co-operatives are viewed as a rather inefficient model by those who frequently look at balance sheets.

A negative view of production co-operatives was found among members who were worried about the co-operative to the extent that they cared about the balance sheet. Hence they understood that the performance of the co-operative was not satisfactory. The same explanation may hold true for members who were not open to information about events in the co-operatives.

D_participgenass_5: The effect of participation in meetings was ambiguous, since both moderate and low participation rates were significantly associated with a rather low appreciation of the agricultural co-operative model. However, for the highest participation rates the effect was statistically somewhat weak, indicating that the most frequent participation rates were not necessarily negative (but also not significantly positive) about the co-operative model.

Members who did not take part in the annual assemblies were not attracted to the cooperative model. These may be people with poor social connections within the membership group, i.e. with weak ties to others. It is also likely that their negative view of the cooperative made them less interested in attending the meetings.

It should be noted that the general assembly has two functions. One is that of being a forum for discussion and information exchange between the members and the leadership. The other is that of a social arena, where members meet each other to socialise. The unclear interpretation of the above-mentioned finding may be a result of the members' appreciation of each of these two functions.

D_willingleader_2: There was a group of respondents who viewed production co-operatives as a good model but had no ambition to become the leader. 
The respondents who considered the co-operative model to be advantageous may realize the difficulties involved in managing business operations as complex as those in a large agricultural firm. They may have a positive view, considering that the present leadership does a good job, but they may believe that they would not be able to do as well themselves. To shed further light on the meaning of this result, the interaction effect between agricultural education and low ambition to become a leader was included:

agriced. $\times$ D_willingleader_2: The respondents who had a relatively high agricultural education and at the same time had no ambition to become a leader were significantly convinced that the co-operative is a rather inefficient model.

A subgroup of the preceding category had a deviating opinion. Those who did not want to be leaders and were well-educated did not appreciate the co-operative form. It may be that the well-educated group had a better understanding of the difficulties involved in running a complex farm so they may think that it is impossible to get good results, even if they themselves were managing the farm.

\section{Trust}

D_leadercareopinion_2 (cares more), D_leadercareopinion_3, D_leadercareopinion_4: Members who felt that the leaders cared about their opinions were less positive to the cooperative.

A negative view of the co-operatives was found among members who believed that the leadership cared about members. A possible explanation for this result is that these members are "troublemakers" that leaders try to appease. They are dissatisfied to the extent that they pose a problem for the leadership.

Closefriendsincoop: Member who stated that they have close friends among the membership were more positive to the co-operative business form.

The members' satisfaction with the co-operative form was better if they had close social ties within the membership group. This shows that the members particularly value the cooperative society.

\section{Satisfaction}

Consideredfamfarmlater: Those who had had ambitions to start their own farm at some point in the past were more positive to the co-operative.

Members who thought that they might start as private farmers within some future liked the co-operative form slightly more, though the difference was not significant. An explanation may be that these individuals hope to amass sufficient capital to allow them to acquire their own farm. However, they had also observed those pioneers in their neighbourhoods who had tried private farming and whose level of living did not improve.

Alternatively, they may have the mentality that the amount they work is related to the results of the farming activities, as private farmers have to do if they are to be successful. Hence, there may to some extent be an entrepreneurial spirit among these members. They have to believe in the co-operative if they are to be successful in their personal endeavours. For those 
who have not succeeded in starting their own farm but have the ambition to do so, a cooperative may appear a relatively attractive substitute.

\section{Loyalty}

D_posopinioncoop_4: Members who seldom noticed positive views about the co-operative considered the co-operative form to be less efficient.

Those who were positive to the co-operative can be expected to get their opinion strengthened as they observe positive events, while the opposite is likely to apply for those who were negative to the cooperative from the outset.

\section{Discussion}

The observations in the preceding section indicate a specific pattern. The members regard the co-operative largely as a social entity, not a production unit. There is a good degree of social capital among the membership, but this is related to the fellow members, not the co-operative enterprise. The members have trust in one another and experience social cohesion, but their trust in the leadership is limited. For the members, the farm is a means to obtain a livelihood, even if this is not very satisfactory. Being a member predominantly fulfils other functions for the individual, except that of being a labourer.

The members do not consider themselves to be business owners. The co-operatives' economic development does not bother the members very much. Quite a few of the members participate in the annual assemblies. However, a general assembly meeting is not only a forum for discussions of the business firm's results, but also a social forum. Another indicator of relative ignorance of the business firm is that members are not interested in taking over the responsibility of leadership. Those who once considered and abandoned the thought of starting private farming have since become more positive to the co-operative model.

The social dimension of membership may be enhanced by the fact that most production cooperatives are continuations of the Soviet farms. The co-operatives have to take responsibility not only for the labour force but also for all inhabitants of a village, some of whom no longer belong to the active labour force. Many members are not needed in production but the cooperative cannot dismiss the redundant workers and they have nowhere else to go.

Members who realize that they are not contributing to production are likely to focus on the social aspects. The worker-members with the best labour opportunities can be expected to leave, whereas the less productive workers remain. There are thus economic and practical problems that follow from the fact that the co-operative is also a social unit and not only an enterprise.

The fact that most production co-operatives are converted Soviet farms means that the cooperatives have the responsibility for all social life in the village. At the time of the conversion the production co-operatives generally took over tasks such as medical care, leisure activities, old age pensions, schooling and other services of a public character. While these services had to be cut compared with Soviet times, the members in general still have access to some basic social services (Davydova and Franks, 2006). 
The heritage of the production co-operatives may explain the fact that the leaders are not in high regard among the members. When the workers of the Soviet farms decided to replace those farms with a co-operative, they were under time pressure so they had no time to consider alternatives (Golovina et al., 2013). Many political and administrative leaders recommended conversion into a co-operative, as the leaders of the former Soviet firms were in favour of a co-operative solution. Hence, even though the legislation states that cooperatives most be established voluntarily, the members did not have much of a choice.

The balance between the social and the economic dimensions has since become skewed. In Soviet times there was a balance in the sense that the two were united. As the co-operative business form was created the economic dimension should have been stressed, but this proved to be impossible. As people have no other income opportunities in the village, they have to consider the co-operative as their "own" firm. The consequence is that the financial results of the co-operative are not considered very much by the members. To them, economic efficiency in terms of input-output relations of the cooperative's production is not important.

As the co-operatives are not a production form in the eyes of the members, the social capital paradigm has a limitation. The members feel a sense of attachment to each other, while their perceived responsibility for the enterprise is weak. The sense of social capital in relation to the firm is limited.

This finding is in line with findings made by Golovina et al. (2013) in a transaction cost theoretical analysis of the Russian agricultural production co-operatives. If the members were to choose an organizational model other than a co-operative, they would have faced exorbitantly high transaction costs. They were locked into the village.

This study presents hard facts to support previous studies which expressed critical views about the role of the leadership in the production co-operatives (Amelina, 2000; AllinaPisano, 2008; Lerman et al., 2004; Valentinov and Nedoborovsky, 2007). “... managers may treat reform ideas (and those that live them) as strange, inappropriate and foreign. They may also withhold information concerning privatization and other civil rights, prevent political organization of farm workers, exclude outsiders ('change agents') from the village, inhibit the creation of support networks or businesses for private farmers, frighten defectors and stress collective identity and local 'collective solutions' to problems." (Petrick and Carter, 2009, p. 237).

The observation that members have social capital in relation to each other may be a reaction to their lack of trust in the leadership. This is especially the case because the members have limited possibilities to get the present leaders replaced by leaders they would trust.

\section{Conclusions}

As the Soviet kolkhozes and sovkhozes were converted, a large number of them became agricultural production co-operatives. Most of these co-operatives still exist and some of them have a strong market position, accounting for almost one-third of the aggregate volume produced by large farms in their particular region.

This paper explored whether social capital might explain the relative success of the cooperatives. It was hypothesized that the members support the co-operatives because they trust 
their fellow members as well as the leadership. This hypothesis was analysed here with the help of a survey among rank-and-file co-operative members in the Kurgan Region. An Ordered Logit Model was used to estimate findings.

The findings indicate that there is social capital in the membership group, although the amount is not overwhelming and it is unevenly distributed. Members who consider cooperatives to be an efficient business form have social ties to other members, while the leadership does not enjoy much social capital within the cooperative. The members regard the co-operative basically as a social unit, not as a business enterprise.

The social capital within the membership group explains members' support of the cooperative society but not support for the co-operative business. Rather, the Russian agricultural production co-operatives continue to exist despite members having little trust in the leadership. Other reasons for the co-operatives' survival may be that competing agricultural enterprises are inefficient, that leaders are striving to preserve their positions, or that regional private markets for agricultural inputs and outputs may still be sufficiently weak to prevent more cooperative members from starting their own business.

\section{References}

Allina-Pisano, J. (2008). The Post-Soviet Potemkin Village. Politics and Property Rights in the Black Earth. Cambridge, Cambridge University Press.

Amelina, M. (2000). Why Russian Peasants Remain in Collective Farms: A Household Perspective on Agricultural Restructuring. Post-Soviet Geography and Economics 41 (7), 483-511.

Binswanger, H., Deininger, K. and Feder, G. (1995). Power, Distortions, Revolt and Reform in Agricultural Land Relations. in: Behrman, J. and Srinivasan, T.N. (eds): Handbook of Development Economics Vol. III. Elsevier. New York, NY, 2659-2772.

Borgen, S.O. (2001). Identification as a Trust-Generating Mechanism in Cooperatives. Annals of Public and Cooperative Economics 72 (2), 208-228.

Bourdieu, P. (1986). The forms of capital. in: J.G. Richardson (ed) Handbook of Theory and Research for the Sociology of Education. New York, Greenwood Press, 241-258.

Davydova, I. and Franks, F.R. (2006). Responses to agrarian reform in Russia: Evidence from Novosibirsk oblast. Journal of Rural Studies 22 (1), 39-54.

Durlauf, S.N. and Fafchamps, M. (2005). Social Capital. in: Aghion, P. and Durlauf, S.N. (eds.): Handbook of Economic Growth. Volume 1B. Amsterdam, Elsevier, 1639-1699.

Eastwood, R., Lipton, M. and Newell, A. (2010). Farm Size. in: Pingali, P.L. and Evenson, R.E. (eds.) Handbook of Agricultural Economics. Vol. 4, Amsterdam, North-Holland, 3323-3397.

Ellis, F. (2000). Rural Livelihoods and Diversity in Developing Countries. Oxford, Oxford University Press.

Ellman, M. (1991). The contradictions of perestroika: The case of agriculture. European Review of Agricultural Economics 18 (1), 1-18.

Feng, L., Friis, A. and Nilsson, J. (2014), Social capital among members in small and large grain marketing cooperatives. Agribusiness 30, (in press).

Golovina, S., Nilsson, J. and Wolz, A. (2013). Members' choice of production co-operatives in the Russian agriculture. Post-Communist Economies 25 (4), 465-491. 
Greene, W.H. and Hensher, D.A. (2008). Modeling ordered choices: A primer and recent developments. Department of Economics (Leonard N. Stern School of Business, New York University), Working Paper No 08-26, June 15th.

Greene, W. H. (2003). Econometric Analysis, 5/e. Pearson Education India.

Hakelius, K. (1996). Cooperative Values. Farmers' Cooperatives in the Minds of the Farmers. Dissertation № 23. Uppsala, Sweden: The Swedish University of Agricultural Sciences.

Hansen, M.H., Morrow Jr., J.L. and Batista, J.C. (2002). The impact of trust on cooperative membership retention, performance and satisfaction: An exploratory study. International Food and Agribusiness Management Review 5, 41-59.

Ioffe, G., Nefdova, T. and De Beurs, K. (2012). Land Abandonment in Russia: A Case Study of Two Regions. Eurasian Geography and Economics 53 (4), 527-549.

James Jr., H.S. and Sykuta, M.E. (2006). Farmer trust in producer- and investor-owed firms: Evidence from Missouri corn and soybean producers. Agribusiness 22 (1), 135-153.

Jones, D.C. and Kalmi, P. (2009). Trust, Inequality and the Size of the Co-operative Sector: Cross-Country Evidence. Annals of Public and Co-operative Economics 80 (2), 165-195.

Kurganrosstat (2011). Agriculture, hunting and forestry in the Kurgan region for 2000, 20062010 (Statistical Collection No. 140). (Сельское хозяйство, охота и лесоводство в Курганской области за 2000, 2006-2010 годы (статистический сборник № 140). Росстат. Территориальный орган федеральной службы государственной статистики по Курганской области. 2011).

Lerman, Z. (1998). Does land reform matter? Some experiences from the former Soviet Union. European Review of Agricultural Economics 25, 307-330.

Lerman, Z. (2010). Agricultural recovery and individual land tenure: Evidence from Central Asia. In: Ferto, I., Forgacs, C. and Jambor, A. (eds.): Changing landscape of European agriculture. Essays in honour of professor Csaba Csaki. Budapest, Agroinform, 95-113.

Lerman, Z., Csaki, C. and Feder, G. (2004). Agriculture in transition, land politics and evolving farm structures in Post-Soviet countries. Lanham, MD, Lexington books.

Morrow Jr., J.L., Hansen, M.H. and Pearson, A.W. (2004). The Cognitive and Affective Antecedents of General Trust within Cooperative Organizations. Journal of Managerial Issues 16 (1), 48-64.

Nilsson, J. and G.T. Svendsen (2011). Free riding or trust? Why members (do not) monitor their co-operatives. Journal of Rural Cooperation 39 (2), 131-150.

Nilsson, J., A. Kihlén and Norell, L. (2009). Are traditional cooperatives an endangered species? About shrinking satisfaction, involvement and trust. International Food and Agribusiness Management Review 12 (4), 103-123.

Nilsson, J., Svendsen, G.L.H. and Svendsen, G.T. (2012). Are large and complex agricultural cooperatives losing their social capital? Agribusiness 28 (2), 187-204.

Österberg, P. and Nilsson, J. (2009). Members' Perception of their Participation in the Governance of Cooperatives: The Key to Trust and Commitment in Agricultural Cooperatives. Agribusiness 25 (2), 181-197.

Petraneva, G., Agibrov, Y. and Ahmetov, R. (2005). Cooperation and agroindustrial integration in APK. Moscow: KolosS (in Russian: Кооперация и агропромышленная интеграция в АПК/ Г.А. Петранёва, Ю.И. Агибров, Р.Г. Ахметов и др.; По ред. Г.А. Петранёвой. - М.: КолосС.- 223 с.).

Petrick, M. and Carter, M.R. (2009). Critical Masses in the Decollectivisation of Post-Soviet Agriculture. European Review of Agricultural Economics 36 (2), 231-252.

Pollak, R.A. (1985). A Transaction Cost Approach to Families and Households. Journal of Economic Literature 23 (2), 581-608. 
Schiller, O. (1969). Co-operation and Integration in Agricultural Production. London, Asia Publishing House.

Schmitt, G. (1993). Why Collectivization of Agriculture in Socialist Countries Has Failed: A Transaction Cost Approach. in: Csaki, C. and Y. Kislev (eds.). Agricultural Cooperatives in Transition. Boulder, Westview Press, 143-159.

Staatz, J. (1984). A Theoretical Perspective on the Behavior of Farmers' Cooperatives. PhD thesis. East Lansing, MI, Michigan State University.

Staatz, J. (1989). Farmer Cooperative Theory: Recent Developments. Washington, DC, USDA, ACS Research Report No. 84.

Staatz, J.M. (1987). The Structural Characteristics of Farmer Cooperatives and their behavioral Consequences. in: Royer, J.S. (ed.): Cooperative Theory: New Approaches. Washington DC; USDA, ACS Service Report 18, 33-60.

Svendsen, G.L.H., and Svendsen, G.T. (2003). The Wealth of Nations: Bourdieuconomics and Social Capital. Theory and Society 32(5/6), 607-631.

Uphoff, N. (1999). Understanding Social Capital: Learning from the Analysis and Experience of Participation. in: Dasgupta, P. and Serageldin, I. (eds.). Social Capital: A Multifaceted Perspective. Washington DC, World Bank, 215-249.

Valentinov, V. and Nedoborovsky, A. (2005). Explaining Inertia in Organizational Change in Ukrainian Agriculture. Journal of Change Management 5 (4), 485-496.

Wegren, S.K. (2014). Rural Inequality in Divided Russia. London and New York, Routledge (Routledge contemporary Russia and Eastern Europe series: 47).

Woolcock, M. (1998). Social Capital and Economic Development: Towards a Theoretical Synthesis and Policy Framework. Theory and Society 27, 151-208.

World Bank (1992). Food and Agricultural Policy Reforms in the Former USSR: An Agenda for the Transition. Washington, DC (Studies of Economies in Transformation, Paper No. $1)$. 
Table 1. Socio-economic structure of the sample $(N=1401)$

\begin{tabular}{lcc}
\hline Attribute & Mean & Std. dev. \\
\hline Age (years) & 43.0 & 12.52 \\
\hline Gender (binary; 1 = male, 2 = female) & 1.57 & 0.49 \\
\hline Household head (binary; 1 = yes, 2 = no) & 1.53 & 0.50 \\
\hline Household size (number of persons) & 3.5 & 0.99 \\
\hline $\begin{array}{l}\text { Education (1 = primary education; 2 = secondary education; 3 } \\
\text { specialist course with degree; 4 = college; 5 = university) }\end{array}$ & 3.3 & 0.92 \\
\hline $\begin{array}{l}\text { Agricultural education (1 = on-the-job only; 2 = specialist course with } \\
\text { degree; 3 = agricultural college; 4 = agricultural university) }\end{array}$ & 2.0 & 0.87 \\
\hline Years of work experience & 23.8 & 12.39 \\
\hline Source: Golovina & &
\end{tabular}

Source: Golovina et al. (2013). 
- $\quad$ reading annual reports (very often $=1$; never $=6$ )

3.97

- $\quad$ attending meetings (very often $=1$; never $=6$ )

- $\quad$ willingness to become leader (yes $=1$; no $=2$ )

- $\quad$ close friends in co-operative (very important $=1$; not at all $=6$ )

- $\quad$ caring leadership (very much $=1$; not at all $=6$ )

- $\quad$ more influence in decision-making than in Soviet times $(\text { yes }=1 \text {; no }=2)^{*}$

- $\quad$ considered private farming after transformation (yes $=1$; no $=2$ )

Loyalty

- $\quad$ positive opinion about co-operative (very often $=1$; never $=6$ )

4.02

1.16

* Those who were too young to answer this question are not included $(\mathrm{N}=816)$ 
Table 3. Impact of social capital dimensions and variables on members' opinions about the efficiency of agricultural production co-operatives in Russian agriculture, marginal effects for the Ordered Logit Model, Delta-method

\begin{tabular}{|c|c|c|c|c|c|}
\hline & $\mathrm{dy} / \mathrm{dx}$ & Std. Err. & $\mathrm{z}$ & $\mathrm{P}>\mathrm{z}$ & \\
\hline \multicolumn{6}{|l|}{ Socio-economic variables } \\
\hline gender & -0.003 & 0.002 & -1.530 & 0.125 & \\
\hline agriceducation & -0.011 & 0.005 & -2.300 & 0.021 & $* *$ \\
\hline \multicolumn{6}{|l|}{ Involvement } \\
\hline D_readbalancesheet_2(read frequent) & 0.015 & 0.007 & 2.080 & 0.038 & $* *$ \\
\hline D_readbalancesheet_3 & -0.001 & 0.003 & -0.520 & 0.607 & \\
\hline D_readbalancesheet_5 & -0.004 & 0.003 & -1.460 & 0.144 & \\
\hline D_readbalancesheet_6(read never) & -0.005 & 0.004 & -1.230 & 0.217 & \\
\hline D_participgenass_2 (participate often) & 0.012 & 0.007 & 1.620 & 0.106 & . \\
\hline D_participgenass_3 & 0.012 & 0.006 & 1.860 & 0.063 & $*$ \\
\hline D_participgenass_4 & 0.011 & 0.006 & 1.670 & 0.095 & $*$ \\
\hline D_participgenass_5 & 0.013 & 0.006 & 2.040 & 0.042 & $* *$ \\
\hline D_participgenass_6 (participate never) & 0.012 & 0.007 & 1.920 & 0.055 & $*$ \\
\hline D_willingleader_2 (dummy=1 if no) & -0.029 & 0.012 & -2.500 & 0.012 & $* *$ \\
\hline agriced. $\times$ D_willingleader_2 & 0.009 & 0.005 & 1.890 & 0.059 & $*$ \\
\hline \multicolumn{6}{|l|}{ Trust } \\
\hline closefriendsincoop & -0.002 & 0.001 & -2.360 & 0.018 & $* *$ \\
\hline D_leadercareopinion_2 (cares more) & 0.016 & 0.006 & 2.910 & 0.004 & $* * *$ \\
\hline D_leadercareopinion_3 & 0.009 & 0.005 & 1.940 & 0.052 & $*$ \\
\hline D_leadercareopinion_4 & 0.012 & 0.005 & 2.300 & 0.021 & $* *$ \\
\hline D_leadercareopinion_5 & 0.007 & 0.005 & 1.510 & 0.130 & \\
\hline D_leadercareopinion_6(cares less) & 0.008 & 0.006 & 1.460 & 0.143 & \\
\hline \multicolumn{6}{|l|}{ Satisfaction } \\
\hline D_ordinarymeminfluence_2 & 0.004 & 0.003 & 1.310 & 0.189 & \\
\hline D_ordinarymeminfluence_3 & 0.004 & 0.003 & 1.230 & 0.217 & \\
\hline consideredfamfarmlater & -0.007 & 0.004 & -1.600 & 0.109 & . \\
\hline \multicolumn{6}{|l|}{ Loyalty } \\
\hline D_posopinioncoop_2 (often) & 0.001 & 0.007 & 0.130 & 0.900 & \\
\hline D_posopinioncoop_3 & 0.001 & 0.003 & 0.400 & 0.691 & \\
\hline D_posopinioncoop_4 & 0.006 & 0.003 & 2.130 & 0.033 & $* *$ \\
\hline D_posopinioncoop_6 (never) & 0.004 & 0.004 & 1.050 & 0.292 & \\
\hline
\end{tabular}

Note: A negative coefficient points to greater appreciation of the agricultural production co-operative as an efficient way of farming. Variable names with " $\mathrm{D}_{-}$" indicate dummy variables; the numbers at the end refer to the corresponding Likert category.

Legend: $* * *$ signif. at $1 \%, * *$ signif. at $5 \%,{ }^{*}$ signif. at $10 \%$, signif. at $12 \%$. 